Original Research Paper

\title{
Inovasi Dan Pengembangan Produk Stik Kangkung Di Desa Dasan Tereng Kabupaten Lombok Barat
}

\author{
Ni Wayan Sri Suliartini' ${ }^{1}$, Made Aditya Budastra ${ }^{2 *}$, Alfan Azizurohman ${ }^{3}$ \\ ${ }^{1}$ Program Studi Agroekoteknologi, Universitas Mataram, Mataram, Indonesia; \\ ${ }^{2}$ Program Studi Akuntansi, Universitas Mataram, Mataram, Indonesia; \\ ${ }^{3}$ Program Studi Hubungan Internasional, Universitas Mataram, Indonesia.
}

https://doi.org/10.29303/jpmpi.v3i2.1005

Sitasi: Suliartini, N. W. S., Budastra, M. A \& Aziurohman, A. (2021). Inovasi Dan Pengembangan Produk Stik Kangkung Di Desa Dasan Tereng Kabupaten Lombok Barat. Jurnal Pengabdian Magister Pendidikan IPA 4(4)

\section{Article history \\ Received: 30 September 2021 \\ Revised: 10 Oktober 2021 \\ Accepted: 28 Oktober 2021 \\ *Corresponding Author: Made Aditya Budastra, Program Studi Akuntansi, Universitas Mataram, Mataram, Indonesia; Email: \\ adityabudastra.ab@gmail.com}

\begin{abstract}
Kangkong can be processed into various types of snacks, one of which is kangkong sticks. Sticks are a type of pastry that has a long flat shape, has a savory taste, and has a crunchy texture. Kangkong sticks are one form of innovation for processed kangkong products. Kangkong sticks were once produced in Dasan Tereng Village, but are no longer produced. Based on the results of interviews and observations conducted by the P1000WB Entrepreneurship Community Service Program (Creation of 1000 New Entrepreneurs), several problems have been found in the kangkong stick product. These problems include; unvaried taste, unattractive packaging, narrow marketing scope, and mass production system. KKN Kewirausahaan made various efforts to re-elevate, as well as develop kangkong stick products into superior products in Dasan Tereng Village. The efforts that have been made are: (1) Providing innovation in the form of flavor variants, (2) Improvement of product packaging using standing pouches, designing, and giving logos, (3) Doing digital marketing and changing the production system to a purchased order (PO) system. The method used is observation, short interview, and literature study. This gives tangible results in the form of product sales which are quite high, exceeding the sales target, from 40 packs to 110 packs in one week.
\end{abstract}

Keywords: Kangkong Sticks; Flavor Variants; Innovation

\section{Pendahuluan}

Tanaman kangkung tergolong jenis sayuran yang sangat terkenal di masyarakat. Kangkung dapat ditanam di dataran tinggi maupun rendah. Kangkung terdiri dari dua varietas, yaitu kangkung darat (ipomea reptans) dan kangkung air (ipomea aquatica). Perbedaan utama dua jenis kangkung ini adalah pada bentuk daun dan warna bunga. Kangkung darat memiliki warna hijau terang dengan ujung daun yang runcing dan berwarna putih. Kangkung air memiliki daun berwana hijau gelap dengan ujung yang membulat atau cukup tumpul, sehingga terlihat lebih lebar (Haryanto, 2009).
Kebutuhan konsumsi sayur, termasuk kangkung, cenderung meningkat dengan meningkatnya kesadaran masyarakat tentang pola hidup sehat. Ketersedian kangkung yang tinggi adalah salah satu faktor pendukung yang menjadikan kangkung sebagai sayuran yang murah dan mudah untuk ditemui. Kangkung banyak ditemukan di pasar tradisional dan supermarket. Komoditas kangkung memiliki nilai ekonomi yang terbilang cukup tinggi dibandingkan dengan komoditas tanaman pangan lainnya, seperti padi dan palawija. Kandungan gizi kangkung juga cukup tinggi terutama vitamin $\mathrm{A}$, vitamin $\mathrm{C}$, zat besi, 
kalsium, protein, fosfor, karoten, hentriakontan, dan sitosterol (Rahman \& Parkpian, 2004).

Kangkung sangat berpotensi untuk dikembangkan karena dapat menjadi salah satu komoditi ekspor andalan bagi Kabupaten Lombok Barat, khususnya Desa Dasan Tereng. Badan Pusat Statistika mencatat bahwa sebagian besar masyarakat Dasan Tereng, Lombok Barat adalah petani sayuran kangkung, disamping sebagian besar juga merangkap sebagai petani padi. Jumlah perbandingan antara luas areal sawah yang ditanami kangkung dan padi adalah sekitar kurang lebih $20 \mathrm{Ha}^{-1}$ ditanami dengan sayuran kangkung dan $43 \mathrm{Ha}^{-1}$ ditanami padi.

Berdasarkan hasil wawancara dengan petani kangkung dan Kepala Desa Dasan Tereng (2021) menunjukkan kangkung dari Desa Dasan Tereng telah berhasil diekspor ke Negara Australia, Saudi Arabia dan Singapura. Sedangkan di dalam negeri, tujuan pengiriman kangkung adalah ke Jakarta dan Surabaya. Dua varietas kangkung yang telah dipatenkan sebagai kangkung yang berasal dari Dasan Tereng adalah Kangkung Aini dan Kangkung Gomong. Kedua varietas kangkung tersebut memiliki tekstur renyah dan memiliki cita rasa yang khas. Hal ini menyebabkan kangkung Dasan Tereng sangat terkenal hingga ke berbagai wilayah tanah air dan manca negara.

Desa Dasan Tereng didukung oleh iklim yang sejuk dengan suhu harian $270^{\circ} \mathrm{C}$, serta adanya air yang selalu tersedia sepanjang tahun, membuat kangkung tumbuh subur dan berkualitas bagus. Hal ini menyebabkan Produksi sayuran kangkung di daerah Dasan Tereng tergolong tinggi dapat mencapai 90 ton.ha $^{-1}$ setiap tahunnya dan tidak kurang dari 35 ton.ha ${ }^{-1} /$ hari. (Profil Desa Dasan Tereng, 2018). Tingginya produksi di Dasan Tereng menyebabkan harga sayuran kangkung seringkali jatuh pada saat produksi yang melimpah karena masa simpan kangkung yang sangat singkat. Hal ini berdampak pada penurunan keuntungan usaha tani kangkung di daerah ini.

Permasalahan dan kendala utama yang dihadapi oleh petani kangkung di daerah Dasan Tereng adalah adanya keterbatasan pengetahuan petani dalam mengenali perilaku pasar sayuran, sehingga petani sangat bergantung pada pedagang atau pengepul dan pemasaran yang masih belum efisien. Permasalahan lainnya adalah rendahnya keterampilan mengembangkan produk sayuran kangkung menjadi produk-produk olahan yang memiliki masa simpan yang lebih lama dan bernilai ekonomis. Oleh karena itu, penting untuk dilakukan pengolahan produk dan pemasaran kangkung dengan keterpaduan berbagai aspek yang saling berkaitan antara satu dengan yang lainnya, yaitu aspek produksi, aspek pengolahan, aspek pemasaran dan konsumsi. Peranan pemerintah dan perguruan tinggi sebagai sumber tenaga ahli dan para peneliti sangat dibutuhkan.

Salah satu program yang sangat tepat dan strategis untuk mendukung kemitraan adalah dalam bentuk kegiatan pengabdian kepada masyarakat dalam rangka "Menciptakan 1000 Wirausaha Baru" yang bergerak dibidang pengolahan makanan berbahan dasar kangkung. Kelompok KKN Desa Dasan Tereng berupaya untuk melakukan inovasi, agar kangkung memiliki nilai ekonomis yang lebih tinggi dan masa simpan lebih lama dan digemari oleh masyarakat luas.

KKN Kewirausahaan Desa Dasan Tereng melihat peluang kangkung dapat diolah menjadi beberapa produk olahan makanan, seperti stik kangkung, ote-ote kangkung, bakso kangkung dan kripik kangkung. Salah satu produk yang dapat diinovasikan dari kangkung, yaitu Stik Kangkung Varian Rasa. Varian rasa tersebut meliputi rasa pedas dengan tingkatan kepedasan yang berbedabeda, balado, BBQ, dan jagung manis. Tujuannya yaitu agar dapat dinikmati oleh semua kalangan usia. Inovasi yang baru ini diharapkan mampu untuk meningkatkan harga dan daya jual kangkung menjadi lebih tinggi, sehingga bisa diterima oleh pasar dan digemari oleh masyarakat luas.

Menurut Pratiwi (2013) stik merupakan salah satu jenis kue kering dengan bahan dasar tepung terigu, tepung tapioka atau tepung sagu, dan telur. Stik tersebut berbentuk pipih panjang, mempunyai rasa yang gurih, serta bertekstur renyah, sehingga disukai oleh masyarakat. Stik tergolong dalam makanan ringan. Pada umumnya, penyimpanan stik dilakukan pada suhu ruang, kemudian dibiarkan dalam keadaan terbuka dan penyimpanan tersebut akan berlangsung sampai stik habis dikonsumsi. Kandungan gizi stik mudah untuk mengalami penurunan mutu, apabila dibiarkan terbuka atau tanpa kemasan pada kondisi suhu ruang yang mengakibatkan perubahan tekstur stik akibat penyerapan uap air dan menurunnya tingkat kerenyahan yang disebabkan oleh reaksi oksidasi komponen lemak. Menurut Triyanto et al. (2013) kemasan dapat mencegah atau mengurangi 
kerusakan, melindungi bahan yang ada di dalamnya dari pencemaran, serta gangguan fisik, seperti gesekan dan benturan.

Melalui kegiatan pengabdian kepada masyarakat ini, kangkung dapat dikembangkan menjadi produk olahan yang bernutrisi dan bernilai jual tinggi dibandingkan dengan bentuk segarnya. Adanya diversifikasi olahan kangkung Lombok menjadi berbagai produk diharapkan akan menambah keanekaragaman hasil olahan kangkung dan dapat meningkatkan konsumsi sayuran kangkung sebagai produk pangan. Oleh karena itu, produk ini memberikan jaminan terserapnya kangkung oleh industri pangan, meningkatnya jumlah permintaan olahan kangkung setiap harinya serta meningkatnya pendapatan masyarakat petani kangkung di daerah Dasan Tereng, Kabupaten Lombok Barat.

\section{Metode}

Pelaksanaan kegiatan pengabdian kepada masyarakat dilaksanakan di Desa Dasan Tereng dalam kurun waktu 31 hari sejak tanggal 21 Juni hingga 21 Juli 2021. Metode pengumpulan data yang digunakan yaitu observasi dan wawancara secara langsung dengan ketua kelompok tani "Nusa Indah" di Desa Dasan Tereng. Tujuan observasi dan wawancara yaitu untuk menemukan masalahmasalah yang ada pada produk stik kangkung yang pernah ada di Desa Dasan Tereng.

Setelah permasalahan dan kendala diketahui, maka dicari solusi untuk memecahkan masalah tersebut melalui pencarian di internet dan diskusi bersama kelompok KKN. Untuk memastikan agar program inovasi yang telah direncanakan dapat terlaksana dengan baik, maka dilakukannya kegiatan pendampingan dalam pembuatan inovasi rasa, kemasan, pemasaran dan sistem produksi kepada kelompok Karang Taruna. Jumlah peserta dari kelompok karang taruna yang mengikuti kegiatan pendampingan ini adalah 4 orang. Hal ini bertujuan agar keberlanjutan dari produk tersebut dapat terlaksanakan dengan baik oleh desa mitra. Seluruh perkembangan yang ada terus diinformasikan dan didiskusikan kepada kelompok Karang Taruna, agar keselarasan pemahaman akan program kegiatan tersebut dapat terealisasi dengan baik. Kelompok karang taruna dipilih sebagai wadah untuk keberlanjutan usaha, karena kelompok tersebut terdiri dari anak-anak muda dari Desa Dasan Tereng, dan juga statusnya baru aktif kembali dikarenakan adanya pandemi Covid-19.

Resep dan Cara Pembuatan

A. Resep

- Margarin (8 sdm)

- Masako (2 bungkus)

- Tepung Terigu Segitia Biru $(2 \mathrm{~kg})$

- Tepung Tapioka (400 gr)

- Kangkung (400 gr)

- $\quad \operatorname{Garam}(2,5 \mathrm{sdt})$

- Telur (8 butir)

- Bumbu perasa; Balado/BBQ/Jagung Manis/Pedas Tingkatan 1,2,3 (2 sdt)

B. Cara Pembuatan

1. Menyiapkan bahan-bahan yang akan digunakan.

2. Kangkung dicuci hingga bersih, kemudian dipotong dengan ukuran yang kecil $(1 \mathrm{~cm})$.

3. Potongan kangkung diblender hingga halus.

4. Kangkung dicampur dengan bahan-bahan lainnya, kemudian diuleni hingga merata.

5. Adonan digiling kemudian dibentuk menjadi pipih panjang.

6. Selanjutnya adonan yang sudah dibentuk digoreng hingga matang, kemudian ditiriskan.

7. Tambahkan bumbu perasa yang diinginkan sesuai dengan takaran yang telah ditentukan.

\section{Hasil dan Pembahasan}

Seluruh rangkaian kegiatan pengabdian kepada masyarakat di Desa Dasan Tereng yang berkaitan dengan pemberian inovasi terhadap produk stik kangkung telah dilaksanakan dengan melibatkan kelompok tani dan kelompok karang taruna. Berdasarkan hasil observasi dan wawancara terhadap kelompok tani di Desa Dasan Tereng, telah ditemukan beberapa permasalahan yang ada pada produk stik kangkung tersebut. Secara umum, permasalahan tersebut meliputi, (1) rasa, (2) kemasan, dan (3) pemasaran dan sistem produksi.

Pertama, permasalahan yang dihadapi adalah terkait dengan rasa dari produk stik kangkung yang ditawarkan. Produk stik kangkung yang dahulu diproduksi di Desa Dasan Tereng hanya menawarkan satu jenis rasa, yaitu rasa orisinil (asin). Hal tersebut berpotensi untuk membuat konsumen merasa bosan. Di samping itu, 
lingkup kalangan pembeli menjadi sempit, sehingga kemungkinan produk tersebut ditinggalkan akan semakin tinggi. Berinovasi dengan menciptakan beragam varian rasa maka produk yang dihasilkan tentunya dapat disukai serta diminati oleh konsumen (Rawi et al., 2019). Oleh karena itu, inovasi rasa merupakan komponen yang sangat penting dalam upaya meningkatkan nilai dari produk stik kangkung tersebut.

Permasalahan kedua adalah terkait dengan kemasan. Produk stik kangkung yang dahulu diproduksi pada Desa Dasan Tereng dikemas dengan menggunakan plastik bening. Kemasan ditutup dengan dua macam alternatif, yaitu dibakar dengan lilin atau disteples. Kelemahan lainnya yaitu komponen logo yang digunakan untuk pengenalan produk kurang menarik, karena hanya menggunakan kertas putih yang dituliskan nama produk, tanpa adanya logo khusus yang menjadi ciri khas dari produk. Oleh karena itu, inovasi kemasan dan penciptaan logo yang menarik merupakan komponen yang sangat penting untuk dapat memberikan nilai tambah pada produk stik kangkung di Desa Dasan Tereng

Ketiga, permasalahan yang dihadapi adalah terkait dengan pemasaran. Kegiatan pemasaran produk stik kangkung hanya dilakukan di wilayah Dasan Tereng dengan cara menitipkan di warungwarung kecil, minimarket, dan rumah makan. Berdasarkan hal tersebut, dapat dikatakan bahwa cakupan pemasaran dari produk stik kangkung tersebut terbilang sempit, karena belum menjangkau konsumen yang ada di berbagai penjuru Pulau Lombok, atau bahkan seluruh Indonesia. Di samping masalah pemasaran, proses produksi dilakukan secara masal, dimana proses produksi tetap dilakukan sesuai target yang ditetapkan, walaupun produk sebelumnya belum terjual di pasaran. Hal ini berpotensi merugikan kegiatan usaha, ketika produk yang dipajang tidak diminati oleh konsumen (produk rusak dan kualitasnya menurun). Oleh karena itu, inovasi dalam pemasaran dan sistem produksi juga merupakan komponen yang sangat penting untuk dapat memberikan nilai tambah pada produk stik kangkung tersebut.

Berdasarkan permasalahan yang telah dipaparkan sebelumnya, maka inovasi dan pengembangan yang akan dilakukan meliputi tiga hal, yaitu; (1) Inovasi rasa, (2) Inovasi kemasan, dan (3) Inovasi pemasaran dan sistem produksi.

\section{Inovasi Rasa}

Cita rasa merupakan satu hal yang paling krusial dalam suatu produk olahan makanan, karena hal tersebut merupakan komponen pembeda antara makanan satu dengan yang lainnya. Cita rasa ini meliputi beberapa atribut yang ada dalam makanan, seperti tampilan, aroma, rasa, tekstur, dan juga suhu (Drummond \& Brefere, 2010). Upaya untuk meningkatkan cita rasa tersebut dapat dilakukan dengan menggunakan bahan tambahan makanan, seperti penyedap rasa (Garrow \& James, 1993). Peningkatan varian rasa diberikan pada rasa orisinil yang asin ditambah dengan varian penyedap rasa lainnya.

Berdasarkan hal tersebut, upaya pertama yang dilakukan adalah dengan memberikan inovasi berupa varian rasa pada produk stik kangkung di Desa Dasan Tereng.

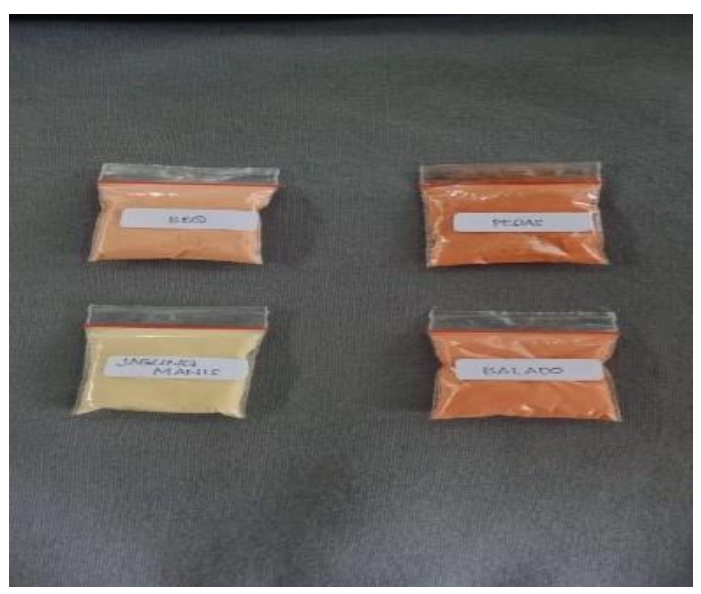

Gambar 1. Varian Rasa Stik Kangkung

(Sumber: Dokumentasi Pribadi)

Beberapa varian rasa dipilih dengan mempertimbangkan varian rasa yang sedang tren/populer pada saat ini. Varian rasa tersebut antara lain; balado, BBQ, jagung manis, dan pedas dengan tingkat kepedasan yang berbeda (Gambar 1). Berbagai rasa tersebut banyak dijumpai pada produk-produk olahan makanan saat ini, terutama cemilan, sehingga dianggap sebagai rasa yang kekinian yang diminati berbagai kalangan usia. Oleh karena itu, dengan penambahan berbagai macam varian rasa ini diharapkan dapat meningkatkan daya tarik, minat, dan ruang lingkup konsumen untuk membeli produk stik kangkung tersebut di Desa Dasan Tereng. 


\section{Inovasi Kemasan}

\section{A. Perbaikan Kemasan}

Menurut Kamus Besar Bahasa Indonesia (KBBI) (2008) kemasan adalah wadah pelindung barang dagangan (niaga). Perbaikan terhadap kemasan merupakan hal yang sangat penting, karena kemasan berisi tentang gambaran singkat mengenai suatu produk. Ketika kemasan yang digunakan menarik dan memiliki nilai estetika yang tinggi, maka berpotensi untuk membuat konsumen tertarik, dan sekaligus mempengaruhi keputusannya dalam pembelian. Proses pemilihan kemasan dilakukan dengan menganalisis kemasan-kemasan yang banyak digunakan oleh produk kekinian pada saat ini.

Keputusan akhir terkait pemilihan jenis kemasan produk yaitu menggunakan kemasan dengan jenis standing pouch (Gambar 2). Alasan pemilihan jenis kemasan standing pouch adalah kemasan tersebut menyediakan inovasi berupa klip untuk memudahkan konsumen dalam membuka ataupun menutup produk stik kangkung. Alasan lainnya adalah memudahkan konsumen dalam hal penyimpanan, tanpa harus menggunakan wadah tambahan. Kemasan produk dengan jenis standing pouch memiliki harga yang lebih mahal dibandingkan kemasan dengan jenis plastik bening, tetapi kemasan tersebut memiliki nilai estetika yang lebih baik dan lebih mewah.

Kemasan standing pouch membuat produk dapat disimpan lebih tahan lama (kedap udara). Harga dari kemasan standing pouch tersebut adalah Rp. 1.150/pcs, sedangkan untuk kemasan dengan jenis plastik bening seharga Rp. 208/pcs.

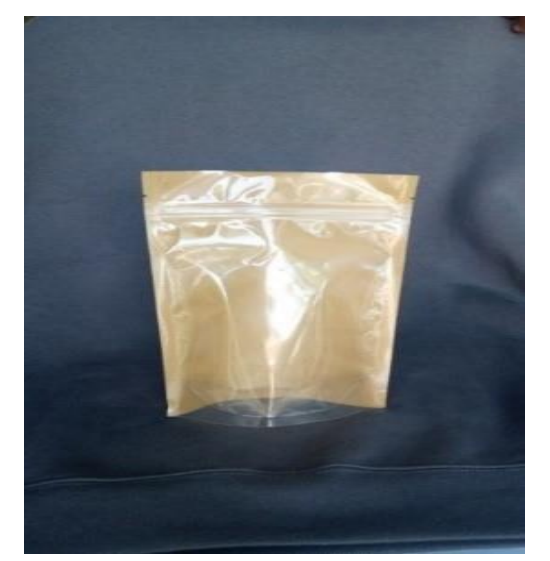

Gambar 2. Kemasan Standing Pouch

(Sumber: Dokumentasi Pribadi)
Setelah menentukan jenis kemasan yang akan digunakan, tahapan selanjutnya adalah menentukan desain dari kemasan tersebut. Desain kemasan merupakan alat komunikasi yang digunakan untuk mengaitkan antara bentuk, material, struktur, warna, tipografi, citra, dan elemen-elemen desain bersama informasi produk agar dapat dipasarkan (Klimhuck \& Krasovec, 2007). Salah satu fungsi penting dari desain kemasan adalah membedakan antara sebuah produk dengan produk pesaing di pasar (Cenadi, 2000). Bentuk desain yang digunakan adalah menambahkan stiker yang berisi keterangan komposisi produk, latar berwarna, pilihan rasa, kontak, dan berbagai akun media sosial usaha (facebook, whatsapp, dan instagram) (Gambar 3). Kegiatan pendesainan kemasan diharapkan mampu mempercantik tampilan kemasan dari produk stik kangkung, agar dapat meningkatkan nilai estetika produk di mata konsumen.

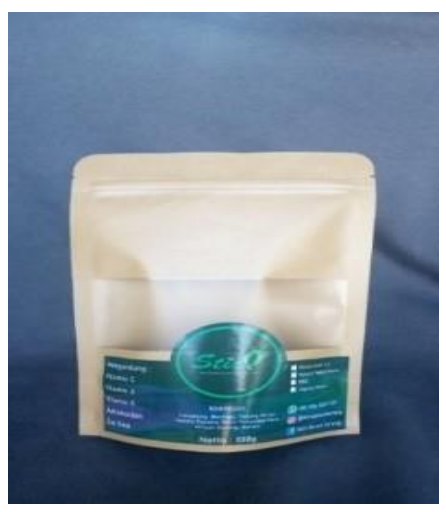

Gambar 3. Desain Kemasan Produk

(Sumber: Dokumentasi Pribadi)

\section{B. Pembuatan Logo}

Logo atau stiker kemasan merupakan suatu alat yang menggambarkan identitas visual terkait suatu produk yang memiliki kriteria tertentu sebagai ciri khasnya. Fungsi dari adanya logo adalah untuk menanamkan produk didalam benak konsumen agar selalu diingat, sekaligus untuk meningkatkan citra dari produk itu sendiri. Pembuatan logo sebaikya dilakukan dengan bentuk yang sederhana, tetapi mengandung unsur ciri khas dari produk itu sendiri, mudah untuk di deskripsikan, mengunggah, memiliki unsur keaslian, dan tidak memiliki unsur kemiripan dengan logo pada produk lain (Wardanu et al., 2018). 
Pertimbangan pembuatan logo dilakukan melalui diskusi, bahwa logo tersebut harus sederhana dan memuat kekhasan dari produk stik kangkung. Keputusan akhir dari pembuatan logo dilakukan dengan memasukan beberapa komponen penting yang menjadi ciri khas produk didalamnya. Produk tersebut diberi nama 'SticQ'. Pada font tulisan, bentuk yang dipilih adalah bentuk yang menyerupai batang kangkung, dan diwarnai dengan hijau, agar menyerupai kangkung. Huruf ' $i$ ' dari 'SticQ' diberikan ilustrasi dari daun kangkung, agar ciri khas kangkung dari produk tersebut dapat terlihat. Pada huruf 'Q' dari 'SticQ' diberikan ilustrasi mahkota, yang artinya produk tersebut akan selalu berjaya sepanjang waktu. Inovasi dalam bentuk pemberian logo unik tersebut diharapkan mampu untuk melekatkan produk stik kangkung varian rasa dalam benak konsumen.



Gambar 4. Logo Produk (Sumber: Dokumentasi Pribadi)

\section{Inovasi Pemasaran \& Sistem Produksi}

Pemasaran adalah suatu proses sosial, dimana kelompok atau individu memperoleh apa yang mereka butuhkan atau inginkan dengan cara menciptakan produk, kemudian mempertukarkan produk tersebut kepada kelompok atau individu lainnya (Irawan et al., 1998). Secara sederhana, pemasaran dapat diartikan sebagai suatu upaya untuk memenuhi kebutuhan melalui cara yang menguntungkan. Tujuan utama dari pemasaran yaitu untuk mengenal dan memahami konsumen, sehingga produk yang akan dibuat dapat sesuai dengan apa yang mereka inginkan. Ketika produk yang dibuat telah sesuai dengan keinginan konsumen, maka produk tersebut akan laku di pasaran dan memberikan keuntungan.

Pada saat ini, perkembangan teknologi sangat pesat, akibatnya terdapat banyak perubahaan dalam berbagai aspek kehidupan manusia, salah satunya adalah kegiatan pemasaran. Secara tradisional, kegiatan pemasaran cenderung dilakukan secara langsung, dengan terjun langsung ke lapangan untuk bertemu konsumen.
Perkembangan teknologi menyebabkan kegiatan pemasaran dapat dirubah menjadi suatu bentuk alternatif yang tidak mengharuskan penjual bertemu secara langsung dengan konsumen, tetapi dengan memanfaatkan media digital yang tersedia pada saat ini.

A. Promosi

Dalam kegiatan pemasaran, salah satu komponen yang tidak dapat dipisahkan adalah promosi. Promosi adalah bagian serta proses dari strategi pemasaran yang digunakan sebagai sarana untuk berkomunikasi dengan pasar menggunakan komposisi bauran promosi (Kotler, 2000). Promosi berfungsi untuk memperkenalkan produk beserta informasi-informasi yang terdapat didalamnya kepada konsumen. Sesuai dengan permasalahan yang ada, maka inovasi kegiatan pemasaran yang dilakukan yaitu pemasaran secara digital.

Kegiatan promosi produk stik kangkung varian rasa menggunakan beberapa platform media sosial, seperti facebook, instagram, dan whatsapp. Proses promosi tersebut dilakukan dengan cara menyebarkan pamflet produk yang berisi foto produk, logo, pilihan rasa, kontak usaha, dan juga harga (Gambar 5). Feedback konsumen terkait produk stik kangkung varian rasa digunakan sebagai selingannya (Gambar 6).

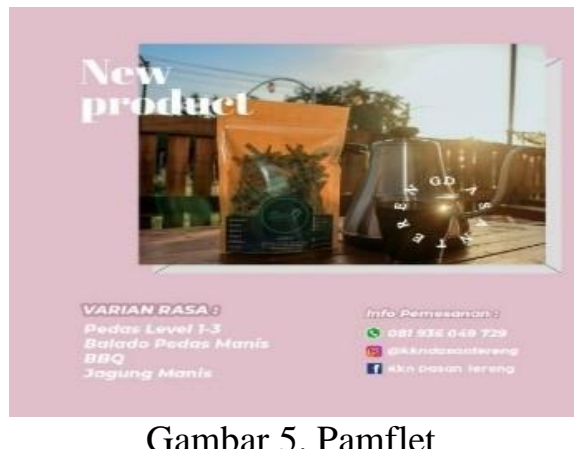

(Sumber: Dokumentasi Pribadi)

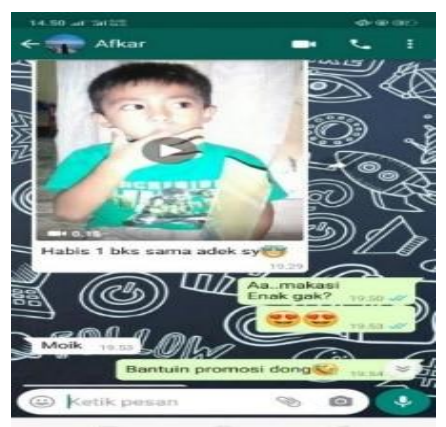

Gambar 6. Feedback Konsumen 


\section{(Sumber: Dokumentasi Pribadi)}

\section{B. Sistem Produksi \& Distribusi}

Proses produksi dilakukan setelah menerima pesanan masuk, karena sistem produksi yang dipilih adalah purchased order (PO). Tujuannya adalah untuk mempertahankan kualitas produk agar selalu terjaga dan tidak rusak, serta mencegah terjadinya kerugian penjualan. Sistem ini merupakan bentuk inovasi dari produk stik kangkung terdahulu di Desa Dasan Tereng, dimana kegiatan produksi dilakukan secara masal, dan cenderung bersifat merugikan ketika produk tersebut tidak laku di pasaran.

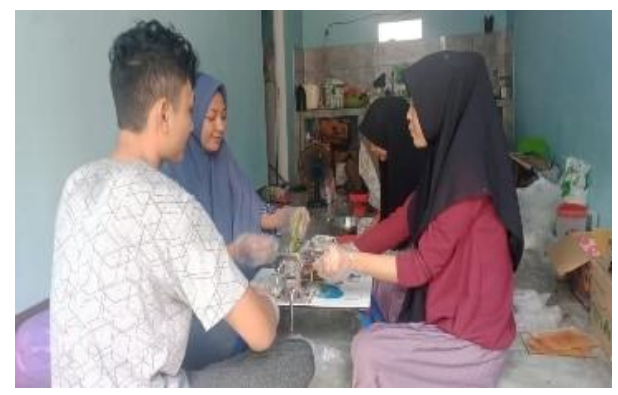

Gambar 7. Proses Produksi (Sumber: Dokumentasi Priadi)



Gambar 8. Proses Pendampingan Mitra (Sumber: Dokumentasi Pribadi)

Setelah produk selesai diproduksi dan dikemas, maka tahapan akhir yang dilakukan adalah distribusi. Distribusi merupakan komponen yang sangat penting dalam kegiatan pemasaran, karena bertujuan untuk mengirim produk ke tangan konsumen. Sistem yang dipilih untuk kegiatan distribusi adalah sistem cash on delivery (COD), yaitu pembayaran produk dilakukan setelah barang sampai di tangan konsumen. Hal tersebut bertujuan untuk menghilangkan keraguan konsumen akibat barang tidak dikirim setelah menstransfer uang dan produk dipastikan sampai ke tangan konsumen. Kegiatan pengantaran melalui sistem COD ini tidak dikenai tambahan biaya (gratis) untuk daerah Lombok Barat dan Mataram, bertujuan meningkatkan minat konsumen dalam memesan produk. Sesuai dengan kondisi pandemi covid-19 saat ini yang menyebabkan situasi menjadi kurang kondusif, kegiatan COD dilakukan dengan menerapkan protokol kesehatan yang ketat untuk mencegah penularan covid-19.

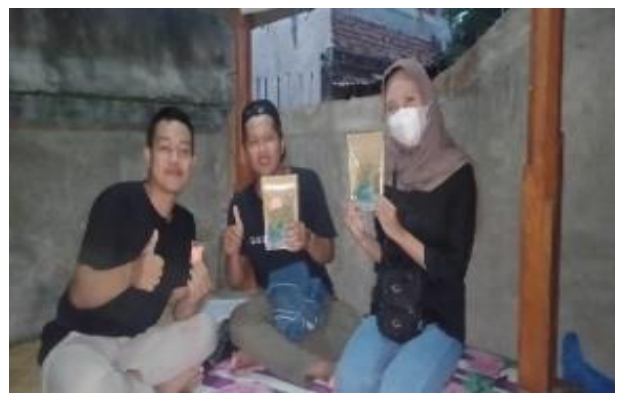

Gambar 9. Distribusi Dengan Sistem COD

(Sumber: Dokumentasi Pribadi)

Secara umum dalam implementasi kegiatan berbagai bentuk inovasi yang dilakukan telah berhasil. Hal ini dapat dilihat dari jumlah pesanan produk yang melampaui target penjualan sebanyak 110 bungkus dalam 1 pekan, sementara target penjualan yang ditetapkan selama periode KKN adalah 40 bungkus. Produk stik kangkung varian rasa juga berhasil terjual baik di dalam daerah (Lombok Timur, Lombok Utara, Lombok Barat, dan Mataram) maupun luar daerah (Tanggerang). Oleh karena itu, prospek dari usaha stik kangkung varian rasa ini menjanjikan.

Setelah kelompok KKN ditarik dari desa mitra, kelompok Karang Taruna telah memulai kegiatan produksi produk stik kangkung varian rasa tersebut sesuai dengan apa yang telah diajarkan oleh kelompok KKN pada saat kegiatan pendampingan. Hasilnya, produk yang dihasilkan telah sesuai dengan yang diajarkan kelompok KKN. Kelompok Karang Taruna juga sudah mulai memasarkan produk tersebut kepada konsumen dengan memanfaatkan media sosial yang ada.

\section{Kesimpulan}

Berdasarkan pembahasan tersebut, dapat ditarik kesimpulan bahwa terdapat peningkatan pengetahuan dan pemahaman mitra terkait pentingnya melakukan inovasi produk. Selain itu, terjadinya peningkatan penjualan produk stik kangkung setelah dilakukannya penambahan inovasi rasa, perbaikan kemasan, pemanfaatan 
media sosial sebagai sarana pemasaran, dan penggunaan sistem purchased order (PO). Kemudian, Desa mitra yang diwakilkan oleh kelompok Karang Taruna telah mulai menjalankan kegiatan usaha produk stik kangkung varian rasa setelah kelompok KKN meninggalkan lokasi desa mitra.

\section{Ucapan Terima Kasih}

Terima kasih kelompok KKN Desa Dasan Tereng ucapkan kepada Dr. Ni Wayan Sri Suliartini, S.P, M.P. selaku Dosen Pembimbing Lapangan (DPL) yang telah membimbing dan memberikan arahan selama pelaksanaan KKN. Tidak lupa juga kelompok KKN mengucapkan terima kasih kepada seluruh seluruh aparatur/perangkat desa yang telah membantu dalam menyukseskan seluruh rangkaian program kerja yang telah disusun.

\section{Daftar Pustaka}

Cenadi, C. S. 2000. Peranan Desain Kemasan Dalam Dunia Pemasaran. Nirmana 2(2): 92103.

Drummond, K. E., \& L. M. Brefere. 2010. Nutrition For Foodservice And Culinary Proffesional's. New Jersey: Jhon Wiley \& Sons.

Garrow, J. S., \& W. P. T. James. 1993. Human Nutrition And Dietetics. Edinburgh: Churcill Livingstone.

Haryanto. 2009. Bertanam Kangkung Raksasa Di Pekarangan. Yogyakarta: Kanisius.

Irawan., Faried Widjaya, \& Sudjoni. 1998. Pemasaran: Prinsip Dan Kasus. Yogyakarta: BPFE.

Klimhuck, M. R., \& S. A. Krasovec. 2007. Desain Kemasan. Jakarta: Erlangga.

Kotler, P. 2000. Manajemen Pemasaran. Jakarta: Prehallindo.

Pratiwi, F. 2013. Pemanfaatan Tepung Daging Ikan Layang Untuk Pembuatan Stik Ikan. Skripsi. Univesitas Negeri Semarang.

Rahman, M. M, \& Preeda Parkpian. 2004. Distribution of Arsenic in Kangkong (Ipomoea Reptans). ScienceAsia 30(3): 255.

Rawi, R. D. P, Ramli Lewenussa, \& Karmila. 2019. Pelatihan Pembuatan Keripik Pisang Sebagai Sarana Peluang Bisnis Dan Kreatifitas Mahasiswa Fakultas Ekonomi Universitas Muhammadiyah Sorong. Abdimas: Papua Journal of Community Service 1(2): 24.
Triyanto, E., B. W. H. E, Prasetiyono, \& S. Mukodiningsih. 2013. Pengaruh Bahan Pengemasan Dan Lama Simpan Terhadap Kualitas Fisik Dan Kimia Wafer Pakan Komplit Berbasis Limbah Agroindustri. Animal Agriculture Journal 2(1): 400-409.

Wardanu, A. P, Martanto, \& Uliyanti. 2018. Perbaikan Desain Kemasan Stik Ale-Ale Dan Stik Kangkung Produksi Kub Wida Mantolo Di Kecamatan Benua Kayong Kabupaten Ketapang. Difusi 1(2): 11-21. 